\title{
Front Matter: Volume 9764
}

, "Front Matter: Volume 9764," Proc. SPIE 9764, Complex Light and Optical Forces X, 976401 (29 July 2016); doi: 10.1117/12.2239906

SPIE. Event: SPIE OPTO, 2016, San Francisco, California, United States 


\title{
PROCEEDINGS OF SPIE
}

\section{Complex Light and Optical Forces $X$}

\author{
Jesper Glückstad \\ David L. Andrews \\ Enrique J. Galvez \\ Editors
}

\section{6-18 February 2016}

San Francisco, California, United States

Sponsored by

SPIE

Cosonsored by

ICOAM (United States)

Published by

SPIE 
The papers in this volume were part of the technical conference cited on the cover and title page. Papers were selected and subject to review by the editors and conference program committee. Some conference presentations may not be available for publication. Additional papers and presentation recordings may be available online in the SPIE Digital Library at SPIEDigitallibrary.org.

The papers reflect the work and thoughts of the authors and are published herein as submitted. The publisher is not responsible for the validity of the information or for any outcomes resulting from reliance thereon.

Please use the following format to cite material from these proceedings:

Author(s), "Title of Paper," in Complex Light and Optical Forces X, edited by Jesper Glückstad, David L. Andrews, Enrique J. Galvez, Proceedings of SPIE Vol. 9764 (SPIE, Bellingham, WA, 2016) Sixdigit Article CID Number.

ISSN: 0277-786X

ISSN: 1996-756X (electronic)

ISBN: 9781628419993

Published by

SPIE

P.O. Box 10, Bellingham, Washington 98227-0010 USA

Telephone +1 3606763290 (Pacific Time) · Fax +1 3606471445

SPIE.org

Copyright (c) 2016, Society of Photo-Optical Instrumentation Engineers.

Copying of material in this book for internal or personal use, or for the internal or personal use of specific clients, beyond the fair use provisions granted by the U.S. Copyright Law is authorized by SPIE subject to payment of copying fees. The Transactional Reporting Service base fee for this volume is $\$ 18.00$ per article (or portion thereof), which should be paid directly to the Copyright Clearance Center (CCC), 222 Rosewood Drive, Danvers, MA 01923. Payment may also be made electronically through CCC Online at copyright.com. Other copying for republication, resale, advertising or promotion, or any form of systematic or multiple reproduction of any material in this book is prohibited except with permission in writing from the publisher. The CCC fee code is 0277-786X/16/\$18.00.

Printed in the United States of America.

Publication of record for individual papers is online in the SPIE Digital Library.

\section{SPIE. DIGITAL}

Paper Numbering: Proceedings of SPIE follow an e-First publication model. A unique citation identifier (CID) number is assigned to each article at the time of publication. Utilization of CIDs allows articles to be fully citable as soon as they are published online, and connects the same identifier to all online and print versions of the publication. SPIE uses a six-digit CID article numbering system structured as follows:

- The first four digits correspond to the SPIE volume number.

- The last two digits indicate publication order within the volume using a Base 36 numbering system employing both numerals and letters. These two-number sets start with 00, 01, 02, 03, 04, $05,06,07,08,09,0 A, 0 B \ldots$ OZ, followed by 10-1Z, 20-2Z, etc. The CID Number appears on each page of the manuscript. 


\title{
Contents
}

\author{
vii Authors \\ ix Conference Committee \\ xi Introduction
}

\section{SESSION 1 TOAST TO 10TH YEAR OF COMPLEX LIGHT AND OPTICAL FORCES}

976402 Overview of selected seminal optical science and photonics processes in nature (Invited Paper) [9764-1]

976403 Transverse spin and momentum in structured light: quantum spin Hall effect and transverse optical force (Invited Paper) [9764-2]

\section{SESSION 2 QUANTUM ASPECTS}

976407 Quantum issues with structured light [9764-7]

976408 Satisfying the Einstein-Podolsky-Rosen criterion with massive particles [9764-8]

\section{SESSION 3 MICROFABRICATION FOR BEAM ENGINEERING}

9764 OA A platform for lab and industrial scale replication of phase optics and microfluidics (Invited Paper) [9764-10]

$9764 \mathrm{OB}$ Structured amplitude and phase fields behind microstructures: the quest for high contrast modulation at proximity (Invited Paper) [9764-11]

9764 OC Compact solutions for optical fiber tweezers using Fresnel zone and phase lenses fabricated using FIB milling (Best Student Paper Award) [9764-12]

\section{SESSION 4 BEAM ENGINEERING AND APPLICATIONS}

9764 OF Cell sorting using efficient light shaping approaches [9764-15]

9764 OH Dark GPC [9764-17]

976401 Generation of complex light using uniaxial and biaxial crystals: an efficient and accurate vectorial simulation technique [9764-59] 
$97640 \mathrm{~J}$ Optical quantification of forces at play during stem cell differentiation (Invited Paper) [9764-18]

$9764 \mathrm{OL}$ Measurement and accumulation of electric charge on a single dielectric particle trapped in air [9764-20]

$976400 \quad$ Mapping the spectral twist of few-cycle vortex pulses [9764-23]

SESSION 6 SUPERPOSITION EFFECTS

9764 OP Single-beam interference from plain Gaussian and OAM wavefronts (Invited Paper) [9764-24]

$97640 Q \quad$ Generation of Laguerre Gaussian beams using spiral phase diffractive elements fabricated on optical fiber tips using focused ion beam milling [9764-58]

9764 OR High-order disclinations in the polarization of light [9764-26]

9764 OS Soliton formation by interacting Airy beams [9764-27]

SESSION 7 CHIRALITY

9764 OW Chiral separation and twin-beam photonics [9764-30]

SESSION 8 MODES, PROPAGATION, AND TRANSMISSION

9764 OY Untangled modes in multimode waveguides (Invited Paper) [9764-32]

976410 Optical vortex beam transmission with different OAM in scattering beads and brain tissue media (Travel Award) [9764-34]

\section{SESSION 9 NANOSTRUCTURES AND NEAR-FIELD}

976414 Optical binding between nanowires (Invited Paper) [9764-37]

$976416 \quad$ Novel non-imaging optic design for uniform illumination [9764-55]

SESSION 10 PARTICLE TRAPPING, MANIPULATION, AND TRACKING

9764 1A Tractor beams for optical micromanipulation [9764-44]

iv 
9764 1C Holographic vector-wave femtosecond laser processing (Invited Paper) [9764-46]

9764 1D Complex light in 3D printing (Invited Paper) [9764-47]

9764 1E Optical screw-wrench for interlocking 2PP-microstructures [9764-48]

SESSION 12 OPTICAL FORCES: ENHANCEMENT AND OTHER EFFECTS

$9764 \mathrm{IF} \quad$ Photothermal heating in metal-embedded microtools for material transport (Invited Paper) [9764-49]

POSTER SESSION

$97641 \mathrm{~J} \quad$ Photo-induced force for spectroscopic imaging at the nanoscale [9764-53] 
Proc. of SPIE Vol. $9764976401-6$

Downloaded From: https://www.spiedigitallibrary.org/conference-proceedings-of-spie on 26 Apr 2023 Terms of Use: https://www.spiedigitallibrary.org/terms-of-use 


\section{Authors}

Numbers in the index correspond to the last two digits of the six-digit citation identifier (CID) article numbering system used in Proceedings of SPIE. The first four digits reflect the volume number. Base 36 numbering is employed for the last two digits and indicates the order of articles within the volume. Numbers start with 00, 01, 02, 03, 04, 05, 06, 07, 08, 09, OA, OB...0Z, followed by 10-12, 20-2Z, etc.

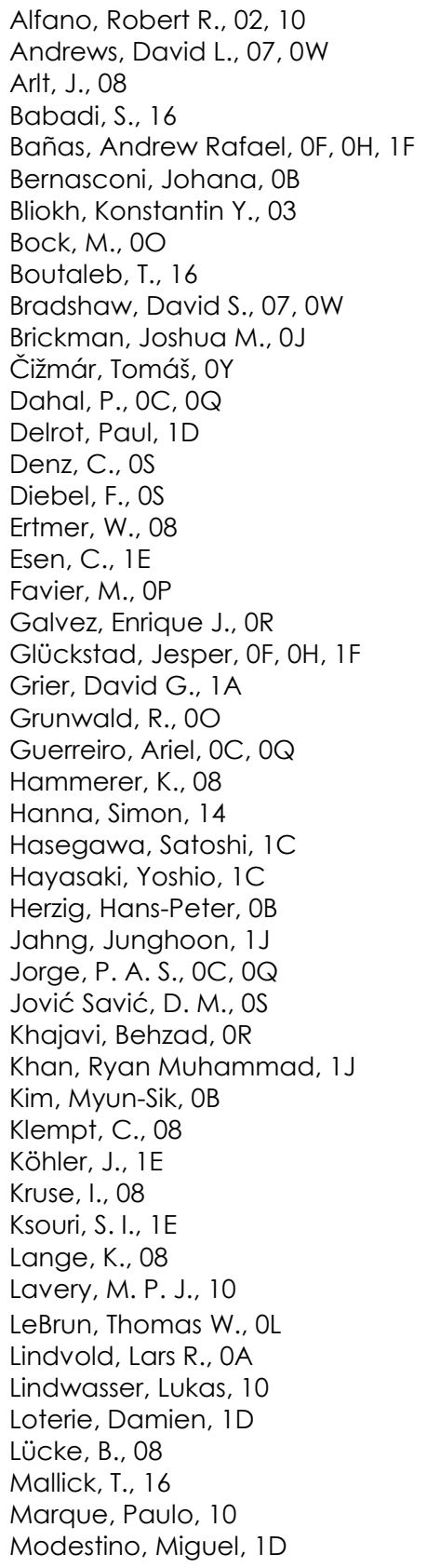


Proc. of SPIE Vol. $9764976401-8$

Downloaded From: https://www.spiedigitallibrary.org/conference-proceedings-of-spie on 26 Apr 2023 Terms of Use: https://www.spiedigitallibrary.org/terms-of-use 


\section{Conference Committee}

Symposium Chairs

Jean-Emmanuel Broquin, IMEP-LAHC (France)

Shibin Jiang, AdValue Photonics, Inc. (United States)

\section{Symposium Co-chairs}

David L. Andrews, University of East Anglia (United Kingdom)

Alexei L. Glebov, OptiGrate Corporation (United States)

Conference Chairs

Jesper Glückstad, Technical University of Denmark (Denmark)

David L. Andrews, University of East Anglia (United Kingdom)

Enrique J. Galvez, Colgate University (United States)

Program Track Chair

Zameer U. Hasan, Temple University (United States)

Conference Program Committee

Robert R. Alfano, The City College of New York (United States)

Cornelia Denz, Westfälische Wilhelms-Universität Münster (Germany)

Kishan Dholakia, University of St. Andrews (United Kingdom)

Wolfgang A. Ertmer, Leibniz University Hannover (Germany)

Andrew Forbes, University of the Witwatersrand (South Africa) and

CSIR National Laser Center (South Africa)

Jörg B. Götte, Max-Planck-Institut für Physik komplexer Systeme (Germany)

David G. Grier, New York University (United States)

Rüdiger Grunwald, Max-Born-Institut für Nichtlineare Optik und Kurzzeitspektroskopie (Germany)

Jandir M. Hickmann, Universidade Federal do Rio Grande do Sul (Brazil)

Thomas R. Huser, Universität Bielefeld (Germany)

Lorenzo Marrucci, Universitá degli Studi di Napoli Federico II (Italy)

Miles J. Padgett, University of Glasgow (United Kingdom)

Darwin Palima, Technical University of Denmark (Denmark)

Monika Ritsch-Marte, Medizinische Universität Innsbruck (Austria)

Halina H. Rubinsztein-Dunlop, The University of Queensland (Australia) 
Marat S. Soskin, Institute of Physics (Ukraine)

Grover A. Swartzlander Jr., Rochester Institute of Technology (United States)

Nirmal K. Viswanathan, University of Hyderabad (India)

\section{Session Chairs}

1 Toast to 10th Year of Complex Light and Optical Forces

David L. Andrews, University of East Anglia (United Kingdom)

2 Quantum Aspects

Enrique J. Galvez, Colgate University (United States)

3 Microfabrication for Beam Engineering

Mark Jayson Villangca, DTU Fotonik (Denmark)

$4 \quad$ Beam Engineering and Applications

Lars R. Lindvold, DTU Risø Campus (Denmark)

5 Measurements and Calibration

Tomáš Cižmár, University of Dundee (United Kingdom)

6 Superposition Effects

Rüdiger Grunwald, Max-Born-Institut für Nichtlineare Optik und Kurzzeitspektroskopie (Germany)

7 Chirality

Lene B. Oddershede, University of Copenhagen (Denmark)

8 Modes, Propagation, and Transmission

Sergei Popov, KTH Royal Institute of Technology (Sweden)

9 Nanostructures and Near-field

Craig B. Arnold, Princeton University (United States)

10 Particle Trapping, Manipulation, and Tracking

Simon Hanna, University of Bristol (United Kingdom)

11 Laser Microfabrication and Microassembly

Kishan Dholakia, University of St. Andrews (United Kingdom)

12 Optical Forces: Enhancement and Other Effects

David L. Andrews, University of East Anglia (United Kingdom) 


\section{Introduction}

This year marked the 10th Anniversary Edition of the conference on Complex Light and Optical Forces that is part of Photonics West. We again had a record number of submissions, indicative of the rising visibility and stature of this conference. Indeed, Complex Light and Optical Forces is still the only yearly venue worldwide for presenting research on complex light. This year we did not find a need to organize joint sessions with other conferences at Photonics West.

The 10th anniversary of our conference had three full days of sessions with the following 12 sessions: Toast to 10th Year of Complex Light and Optical Forces; Quantum Aspects; Microfabrication for Beam Engineering; Beam Engineering and Applications; Measurements and Calibration; Superposition Effects; Chirality; Modes, Propagation and Transmission; Nanostructures and Near-field; Particle Trapping, Manipulation, and Tracking; Laser Microfabrication and Microassembly; Optical Forces, Enhancement and Other Effects. The conference featured more than 60 presentations, with numerous invited, contributed, and poster presentations.

Bringing most of these papers to the SPIE proceedings provides a welcome opportunity to thank all the contributors. In particular, we gladly acknowledge the support of the members of our highly active and supportive Program Committee, whose sterling work underpins the success of this conference each year. We remain indebted to the SPIE staff at every level, for reliable management and production processes, achieved with customary hallmark professionalism.

In summary, the present volume is representative of a strongly growing field of photonics that has contributed much to our understanding of light and its applications in manipulation, and which remains leaving much promise of more to come. 
Proc. of SPIE Vol. $9764976401-12$

Downloaded From: https://www.spiedigitallibrary.org/conference-proceedings-of-spie on 26 Apr 2023 Terms of Use: https://www.spiedigitallibrary.org/terms-of-use 